ЖУКОВИЦЬКИЙ І. В., доктор технічних наук, професор,

СКАЛОЗУБ В. В., доктор технічних наук, професор,

УСТЕНКО А. Б., кандидат технічних наук, доцент,

КЛИМЕНКО І. В., асистент (Дніпропетровський національний університет залізничного транспорту імені академіка В. Лазаряна)

\title{
Формування інтелектуальних інформаційних технологій залізничного транспорту на основі моделей аналітичних серверів та онтологічних систем
}

Досліджено можливості створення уніфікованих інтелектуальних автоматизованих систем залізничного транспорту на основі платформи аналітичних серверів та онтологічних систем, призначених для підтримки конструктивно-продукційного моделювання, а також функиіонування онтологій АСУ, щзо розщирюються та еволюціонують. Для платформи аналітичних серверів розроблено приклад формалізації та реалізації уніфікованих завдань діагностування характеристик виробничих прочесів з нечіткими параметрами.

Ключові слова: інтелектуальні автоматизовані системи, аналітичні сервери, онтологія, діагностування, нечіткі величини.

\begin{abstract}
Вступ
На тепер одним із пріоритетних завдань на залізничному транспорті України є всебічне зменшення експлуатаційних витрат і підвищення ефективності автоматизованої експлуатації широкого кола технолого-економічних процесів (ТЕП) i технічних систем (ТC). Актуальним напрямком щодо реалізації цих завдань $\epsilon$ застосування методів інтелектуальних систем. У цьому напрямку здійснюються розробки сфери формування залізничних інтелектуальних транспортних систем (ЗІТС), створення засобів телематичного управління, спрямованих на підвищення ефективності залізничних перевезень [1, 2]. У статті будуть розглянуті як загальносистемні завдання сфери розвитку 3ІTC, так i безпосередні розробки щодо створення уніфікованих засобів інтелектуальної підтримки автоматизованих систем управління (АСУ) залізничного транспорту України. До загальносистемних завдань та відповідних засобів належать оптимізація управління ТЕП та парків ТС при забезпеченні вимог безпеки, ефективності, зниження впливу транспорту на навколишнє середовище в умовах посилення взаємодії різних видів транспорту тощо.

У подальшому досліджено питання та технології щодо можливостей формування спеціалізованих інтелектуальних інформаційних систем залізничного транспорту України на основі створення платформи аналітичних серверів (АнС) АСУ та онтологічних систем $(\mathrm{OHC})[2,3-5]$. При цьому використовуються
\end{abstract}

уніфіковані моделі та процедури функціонування АнС, які застосовуються для вирішення декількох різнопланових завдань, а саме: оперативного управління процесами раціонального використання локомотивного парку, a також планування та управління процесами експлуатації парків електричних двигунів (ЕД) залізничних стрілочних переводів. У статті подано основні структури та процедури спеціалізованої прикладної онтологічної системи, реалізованої на основі моделі конструктивнопродукційного моделювання (КПМ), а також наведено засоби онтології КПМ, які призначені для формування онтологій систем АСУ, що постійно розвиваються.

Як досить загальний приклад застосування моделей i спеціалізованих засобів АнС подано завдання $з$ діагностування в умовах невизначеності одне 3 базових завдань сфери управління процесами експлуатації парків залізничних ТС. Аналітичний сервіс таких процедур складається із уніфікованого узгодженого комплексу завдань та відповідних математичних моделей, які забезпечують їх формалізацію та подальшу ефективну програмну реалізацію. 


\begin{abstract}
Аналіз досліджень
В інформаційні структури автоматизованих систем

УЗ, зокрема системи АСК ВП УЗ-С, можуть бути вбудовані практично всі технологічні процеси роботи вантажного залізничного транспорту, а також інші технології експлуатації об'єктів УЗ, у тому числі завдання зі створення інтелектуальних систем транспорту [1, 2, 5]. Система автоматизує завдання, які раніше попередньо вирішувалися окремими АСУ на різноманітних технологічних і технічних базах.
\end{abstract}

У роботі [6] були запропоновані принципи створення аналітичних серверів у складі АСК ВП УЗ-С, як певних уніфікованих компонентів систем підтримки прийняття рішень. Також у ній були подані приклади реалізації окремих завдань та процедур прийняття рішень на основі моделей АнС. Розглянемо особливості та методи формування платформи базових функцій АнС, а також онтологічних систем АСУ УЗ.

На тепер усе ширшого застосування отримують інтелектуальні засоби онтологічної підтримки складних, слабко структурованих i наукоємних інформаційних технологій і систем (ITC). Онтологія це система понять, представлена набором сутностей, пов'язаних різними відношеннями, які характеризують певну галузь знань і використовуються для формальної специфікації змістовних компонентів сфери застосування. Наступною суттєвою складовою онтології $\epsilon$ набір аксіом, що забезпечують подання додаткових знань, які не охоплюють ієрархії понять [7-9]. Онтології в явному вигляді широко використовуються як джерела даних для багатьох складних комп'ютерних систем, а саме: формування знань за наборами даних, інформаційний пошук, проектування систем тощо. Перевага онтології полягає в забезпеченні ефективної інтелектуальної обробки складної і різноманітної інформації, а також у можливості багаторазово використовуватися в новому оточенні $[8,10]$. У цей час переважним напрямком досліджень є створення, удосконалення і застосування прикладних онтологій у різних сферах IIT [11].

У $[3,4]$ як спеціалізований об'єкт аналізу, для якого формуються методологічні та формальні засоби онтологічного забезпечення, виступають методи конструктивно-продукційного моделювання. Суттєвими також $є$ оцінки щодо можливості їх використання для онтологічної підтримки діючих зараз в Україні АСУ залізничного транспорту. Головною відмінністю розробок [4] $є$ їх спрямованість на формування засобів онтологічної підтримки процедур КПМ, призначених для реалізації функцій із розвитку складних ITC. Ці засоби необхідні для ЗІТС 3 такими характерними ознаками, як багатоетапність створення, тривалий період функціонування, постійний розвиток технологій об'єкта функціонування тощо. Для забезпечення можливості подання еволюції об'єкта прикладної онтології, а також і змісту системи онтологічної підтримки КПМ (ОКПМ), були сформовані відповідні системи відношень і відображень, створені нові структури формування (породження) моделей тощо. У $[4,5]$ наведено приклади інформаційних технологій в АСУ УЗ, які через високу складність та постійні модифікації потребують онтологічної підтримки. Також показана можливість реалізації діючих процедур розвитку і супроводу складних залізничних АСУ У3 на основі засобів онтологічної підтримки КПМ. Прикладні ОнС виконують кілька ролей у задачах подання знань, відображають таксономічні та інші властивості при концептуалізації, а також можуть реалізувати функції спеціалізованих баз знань. У $[4,8]$ констатується, що «досі не існує загальноприйнятої методології створення онтологій і залишається відкритим питання появи конструктивної теорії розробки формальних онтологій».

Структура моделей i методів платформи АнС повинна враховувати властивості об'єкта та завдання автоматизованого управління [2, 6, 12]. Наприклад, при управлінні парками ТС головні завдання охоплюють такі процеси: запровадження (дистанційного) моніторингу параметрів ТС, класифікація об'єктів парку, діагностування параметрів (визначення поточних та прихованих станів), прогнозування характеристик на зазначений період, планування раціональної черговості обслуговування різного типу. Для парків електричних двигунів у роботах $[1,12]$ для кожного такого завдання наводяться математичні моделі та приклади їх реалізації. Окрім того, форми подання завдань пов'язані безпосередньо з конкретним об'єктом, вони не узагальнені стосовно вимог універсалізації платформи АнС.

\begin{abstract}
Мета
Формування сучасних інтелектуальних інформаційних технологій управління $є$ одним із пріоритетних завдань залізничного транспорту України. Метою цієї статті $€$ дослідження можливостей створення спеціалізованих уніфікованих інтелектуальних систем АСУ ЗТ на основі платформи аналітичних серверів та онтологічних систем, призначених для підтримки конструктивнопродукційного моделювання, а також функціонування онтологій АСУ, що еволюціонують. Для платформи аналітичних серверів необхідно розробити приклад формалізації та реалізації типових завдань АСУ щодо діагностування характеристик виробничих процесів 3 нечіткими параметрами.
\end{abstract}

\begin{tabular}{|c|c|c|c|}
\hline $\begin{array}{l}\text { Процедури } \\
\text { аналітичних с }\end{array}$ & $\begin{array}{c}\text { формування } \\
\text { серверів АСУ УЗ }\end{array}$ & базових & функцій \\
\hline Ієрархічна & структура & юганізації & підр \\
\hline
\end{tabular}


відповідної ієрархії аналітичних функцій підтримки АнС. Розглянемо питання щодо розвитку аналітичної та онтологічної підтримки складних автоматизованих систем керування вантажними перевезеннями УЗ.

Аналітичні сервери системи АСК ВП УЗ-С повинні забезпечувати реалізацію певного набору базових прикладних функцій, які необхідні для підтримки рішень персоналу щодо управління вантажними перевезеннями (УВП) та в інших сферах. Базові функції АнС мають містити такі процедури: одержання та аналітична обробка даних, прогнозування показників динаміки процесу перевезень та інших процесів 3Т, підтримка формування та реалізації завдань із оптимізації певних управлінських рішень, оцінка очікуваних наслідків застосованого управління. Розглянемо засади i методики створення відповідних функціональних підсистем аналітичних серверів АСК ВП УЗ-Є.

Аналітична обробка даних про залізничні процеси в $\boldsymbol{A н C}$ має стати основою багатьох процедур підтримки рішень персоналу 3 УВП та інших, побудованих на аналізі поточної управлінської ситуації та наявних статистичних показниках ефективності. На сьогодні переважна більшість відповідної оперативної i статистичної інформації накопичується в базах і сховищах даних АСК ВП УЗ$\mathcal{C}$, але система не має достатньо розвинених сучасних засобів надання такої інформації користувачам. Одна із складових сучасних систем підтримки рішень (ПР) полягає в можливості для користувачів обирати необхідні «ракурси» аналізу даних, використовувати арсенал стандартних статистичних процедур (інтерполяція, статистичне прогнозування тощо), а також широкий спектр засобів відображення даних у вигляді графіків та діаграм. Нині для цього широко застосовується комплексна технологія OLAP (Online Analyzing Processing), яка використовує спеціальні структури даних - гіперкуби [13]. Окрім того, склад та організація даних у базах АСК ВП УЗ-С суттєво обмежують безпосередне використання підходів OLAP. Наприклад, аналіз УВП виконується із застосуванням значної кількості (декілька десятків) показників, що пов'язані між собою. При цьому облікові дані розміщені насамперед у статистичній базі АСК ВП УЗ-С, яка має досить жорстку структуру. При створенні АнС необхідно зосередитись на розробленні спеціалізованого механізму аналітичної обробки даних АСК ВП УЗ-Є, який відповідає принципам технології OLAP (гнучкий вибір об'єкта аналізу, використання стандартизованого набору статистичних процедур, засобів відображення залежностей тощо). На наступних етапах формування АнС необхідно забезпечити функції дослідження даних методами Data Mining [6].
Прогнозування показників динаміки процесу перевезень та інших процесів $3 T \in$ важливою інтелектуальною складовою функцій управління. Для забезпечення уніфікації процедур прогнозування засобами АнС необхідно визначити їх математичний базис. 3 огляду на існуючі технології отримання та організації даних в АСУ УЗ, а також потреби процесів управління, виділимо такі загальні засади реалізації завдань прогнозування: по-перше, методи математичного прогнозування на основі формування й аналізу часових рядів, які відображають динаміку зміни характеристик ТЕП [2,12,14,15]; по-друге, методи та технології імітаційного моделювання, які базуються на відтворенні логіки розвитку ТЕП у конкретних умовах [15]; по-третє, експертні методи оцінювання станів або тенденцій зміни параметрів ТЕП, що спираються на досвід та інтуїцію експертів, ураховують неформалізовані або приховані залежності тощо [16]; по-четверте, застосування методів інтелектуальних систем, зокрема нечіткого моделювання та управління, а також методів штучних нейронних мереж (ШНМ), які застосовуються для автоматичного формування i адаптації моделей розвитку процесів на основі накопичених i оперативних даних $[17,18]$.

Підтримка процесів прийняття, уніфікація та оптимізація управлінських рішень - комплексне завдання створення платформи АнС у середовищі АСУ УЗ. Подібність процедур широкого кола різних за змістом завдань управління - головна передумова запровадження технологій АнС. Зрозуміло, що при вирішенні конкретних завдань оптимізації на різних рівнях управління необхідно використовувати різноманітні математичні моделі та методи, склад яких буде поступово доповнюватись [19]. Окрім того, у середовищі АнС доцільно застосовувати загальні принципи, уніфіковані процедури і типові інструменти для реалізації таких оптимізаційних завдань. Засоби середовища АнС щодо забезпечення реалізації завдань оптимізації управлінських рішень мають відповідати таким загальним вимогам [20]: провідна роль користувача (інформаційно-дорадчий режим), інтерактивність, онлайновість, апробація наслідків управління, оцінки експлуатаційних показників процесів (імітаційні моделі, аналогічні варіанти та ін.).

Загальна структура методики формування інформаційного забезпечення процесів оптимізації рішень у середовищі АнС подана на рисунку.

Процедури імітаційного моделювання для оцінки характеристик очікуваних наслідків реалізаціі управління. Значна складність об'єктів автоматизованого управління АСУ ЗТ здебільшого не дає змоги отримати загальноприйняті математичні моделі їх функціонування і процесів управління. При 
цьому поведінку і характеристики об’ єктів управління можна дослідити засобами імітаційного моделювання [15]. У цих об'єктах для оцінювання контрольованих показників ефективності багаторазово застосовується прямий модельний експеримент, а хід технологічного процесу відтворюється для різних варіантів збігу випадкових факторів, відображається графічно, у динаміці.

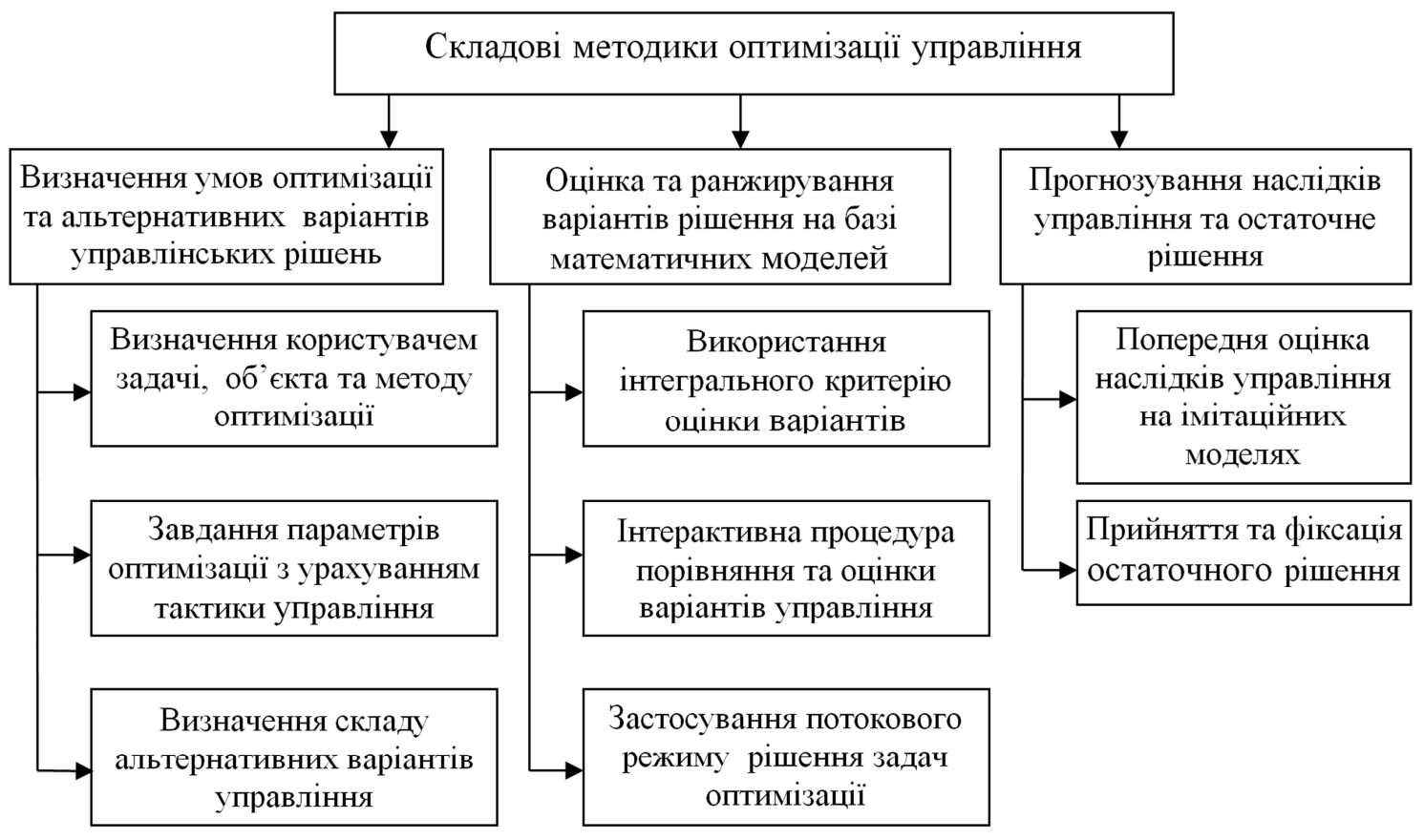

Рис. Структура методики формування та реалізації завдань оптимізації управлінських рішень на платформі АнС

\section{Формування засад онтологічного забезпечення процесів моделювання у середовищі АСУ УЗ}

Для формування засад онтологічного забезпечення АСУ УЗ необхідно дослідити можливість використання певного базового засобу розроблення, зокрема системи методів конструктивнопродукційного моделювання (КПМ). Методологія та засоби онтологічної підтримки процесів КПМ наведені в статтях [3-5]. Серед завдань зі створення прикладної онтології КПМ відзначають такі:

- виявлення i вивчення властивостей структур понять, концептів i основних системоутворюючих відношень при КПМ;

- формулювання вимог до властивостей методології КПМ, а також до спеціалізованих моделей і методів прикладної ОКПМ;

- розроблення єдиної, універсальної, такої, що розвивається та налаштовується на предметні області інформатизації, моделі онтологічної конструктивної структури (ОКС);

- розроблення моделі та процедур, які забезпечують у рамках КПМ можливості створення відношень, структура яких наперед не відома, у тому числі рекурсивних відношень;
- включення в ОКПМ засобів, які дають змогу формувати і супроводжувати концептуальні моделі, відмінні від таксономії;

- урахування факторів невизначеності при виборі структури концептуальних понять предметних областей і їх ознак.

Зупинимося на завданнях формування єдиної онтологічної структури ОКС, як базового інструменту моделювання онтології ОКПМ. Онтологічна система задається первинними наборами абстрактних концептуальних категорій, які є універсальними та визначаються засобами конструювання об'єктів. ОКС задається впорядкованою четвіркою класів: носія $\mathbf{M}$, сигнатури $\Sigma$, числення $\Lambda$ та виконавців Z:

$$
\mathcal{C}=\langle\dot{M}, \dot{\Sigma}, \hat{\Lambda}, \mathfrak{Z}\rangle \text {. }
$$

Класи носія і виконавців дають змогу розглядати структуру (1) як у визначальному, так і в аспектах породжування моделей. Визначальний аспект характеризує носій структури Carr, тобто основну визначальну частину, що за допомогою виконавців 
(пов'язує класи «Вантажі», «Власники», «Перевізники»), «Поїзд» («Локомотив», «Локомотивна внутрішніх виконавців $\mathrm{Z}_{v}$ :

$$
\text { Carr } \stackrel{\dot{z}_{v}}{\longrightarrow} C=\langle\mathrm{M}, \Sigma, \Lambda, \mathrm{Z}\rangle \text {, де } \mathrm{Z}=\dot{Z}_{V} \mathrm{UZ}_{v} \text {. }
$$

Функція породжування (утворення) об'єктів у ОКС (1) проявляється в структурі довільної предметної області $C$ через конструювання саме іiі понятійних об'єктів - носія, сигнатури, числення i внутрішніх виконавців. Клас носія М структури $C$ містить вхідний базис простих об'єктів (екземплярів) $\mathrm{M}_{0}$, абстрактні поняття додаткових символів $D$, елементів класів: операторів, відношень, відображень, конструктивних форм, характеристичних понять, їх показників i значень, класів вільних конструкцій довільного рівня. Носій $\mathrm{M}$ призначений для формування на ньому конкретних понятійних об'єктів. Базисний носій об'єктів $\mathbf{M}_{0} \epsilon$ основоположним для еволюційного формування (такого, що утворює або породжує) родовидових конструктивних класів: об'єктів $O^{k}$, ознак $L^{k}$ і виведених онтологічних об'єктів $O_{*}^{k}$ вищих, тобто утворених моделей наступних $k$-тих рівнів.

Наведене обчислення дає змогу конструювати прості об'єкти-властивості, показники властивостей і їх класи нульового рівня, а також допускає формування простої таксономї онтології ОКПС. Дії операторів реалізуються виконавцями певним чином за алгоритмами. В обчисленні наведені загальні можливості операторів і виконавців, необхідні для конструювання алгоритмів, критеріїв тощо. У (2) передбачені прості відношення підпорядкування, у яких компонента відношень підпорядкування $\mathfrak{R}_{V}^{0} \subset \mathfrak{R}^{0}$ виконує зв'язування об'єктів різної природи в єдину понятійну конструкцію підпорядкування певну сутність, тим самим задаючи основну визначальну складову i також таку, що визначає підпорядковану складову конструкції. На основі базисних відображень з'єднання з різних онтологічних примірників утворюють складні конструкції. Результатом відображення можуть бути неоднорідні конструкції, наділені діями, що, наприклад, дає змогу формувати ознаки 3 діями, які необхідні для породження критеріїв виведення знань, та ін.

Процедури ОКС (2) також забезпечують формування структур системи концептів онтології, відмінних від таксономії. Одним із прикладів необхідності універсальних засобів формування мережевих структур $є$ конструювання і концептуальне моделювання часткових $n$-арних відношень при $n>2$. Такими відношеннями $\epsilon$, наприклад, «Поставка» бригада», «Склад поїзда», «Графік»). Розроблені процедури підтримки ОКПМ, зокрема концептуального моделювання понять області КПМ, забезпечують реалізацію таких вимог, істотно розширюючи сферу інформаційного моделювання систем.

Реалізація цілей ОКПМ стосовно АСУ УЗ є можливою внаслідок існуючої організації діючих систем, а також за рахунок використання ключових методологічних принципів i стандартів створення онтологій предметних областей [7,8]. Реалізація можливості багаторазово використовуватися ОКПМ в новому оточенні, як i в інших прикладних ОнС, забезпечується завдяки створенню потужних засобів концептуального моделювання КПМ. Зазначені властивості ОКПМ надають можливості використання онтологічного методу для підтримки процесів ефективного функціонування АСУ вантажними залізничними перевезеннями, а також їх подальшого розвитку. У роботі [4] виконано розвиток методології КПМ для умов застосування у галузях або складних технологіях, які безперервно розвиваються. Удосконалення моделей та засобів ОКПМ розширює можливості застосування КПМ для інтелектуальної онтологічної підтримки АСУ залізничного транспорту України. Вирішення цього завдання вимагає систематизації та уніфікації класів основних аналітичних задач АСУ в численних сферах автоматизації, розроблення узгодженої системи концептів, створення та всебічної апробації на практиці засобів онтологічного супроводу процесів в y3.

\section{Процедури діагностування в спеціалізованому} аналітичному сервері управління парками ТС

У вступі були наведені приклади базових завдань та функцій АнС щодо управління експлуатацією парків ТС. Серед них одним із головних $є$ завдання діагностування параметрів індивідуальних інтелектуальних моделей, отриманих шляхом застосування (дистанційного) моніторингу. Узагалі процедури діагностування параметрів входять до багатьох завдань управління ТС, тому їх уніфікована аналітична підтримка дуже важлива. Змістовно завдання діагностування (та інформаційні технології щодо забезпечення) полягають у тому, щоб на основі використання результатів вимірів набору контрольованих параметрів об'єкта $\left.\mathbf{X}=\left\{\left(x_{i}\right), \quad i=1,2, \ldots, m\right)\right\} \quad$ визначити його стан щодо діагностування із множини можливих $\left.\mathbf{Y}=\left\{\left(y_{k}\right), \quad k=1,2, \ldots, l\right)\right\}$. Побудова процедур АнС для завдань діагностування (АнС-Д) суттєво залежить 
від характеристик даних $(\mathrm{X}, \mathrm{Y})$, їх обсягів, точності та достовірності. Розглянемо приклад формування уніфікованих процедур діагностування для досить поширеного в умовах виробничих процесів випадку, коли параметри $(\mathrm{X}, \mathrm{Y})$ є або моделюються нечіткими величинами. При цьому структура та функціонування АнС-Д суттєво залежить від моделей відображення умов і методів отримання результатів - логічного висновку $[19,21]$. Для забезпечення потрібного високого ступеня узагальнення завдання та достатньої простоти застосування такого сервісу використаємо результати роботи [21] щодо побудови нечітких експертних систем діагностування станів об'єкта. Процедура АнС-Д, яка узагальнює результати із нечіткого діагностування [21], складається із таких стандартних етапів:

- формування наборів контрольованих параметрів (X) і діагностованих станів (Y), які в подальшому представляють терм-множини лінгвістичної змінної РЕЗУЛЬТАТИ;

- формування функцій належності параметрів $(\mathbf{X})$ терм-множинам значень (Y) змінної РЕЗУЛЬТАТИ:

$\left(\mu_{1}\left(\mathrm{x}_{\mathrm{i}}\right), \mu_{2}\left(x_{i}\right), \ldots, \mu_{l}\left(x_{i}\right)\right), \quad i=1,2, \ldots, m$

- визначення (наприклад за методом аналітичних ієрархій [22]) для кожної терм-множини $y_{k} \in(\mathbf{Y})$ вагових коефіцієнтів важливості параметрів $(\mathbf{X})$ :

$\mathbf{W}^{(k)}=\left(w_{1 k}, w_{2 k}, \ldots, w_{m k}\right), \quad k=1,2, \ldots, L ; \quad \sum_{j} w_{j k}=1 ;$

- отримати значення контрольованого набору параметрів $\left(\mathbf{X}_{*}\right)$, виконати розрахунок набору значень функцій належності для кожної терм-множини значень (Y) змінної РЕЗУЛЬТАТИ:

$\left(\mu_{1}\left(x_{i^{*}}\right), \mu_{2}\left(x_{i^{*}}\right), \ldots, \mu_{l}\left(x_{i^{*}}\right)\right), \quad i=1,2, \ldots, m$

- розрахувати значення результуючих показників терм-множин (можливих станів) 3 урахуванням вагових коефіцієнтів $\mathbf{W}^{(k)}, \quad k=1,2, \ldots, l$;

$\mathbf{V}^{(\mathrm{k})}=\sum_{i} w_{i k} \times \mu_{i k}\left(x_{i^{*}}\right), \quad k=1,2, \ldots, l$.

Величини $\left\{\mathbf{V}^{(k)}\right\}_{l}$ показують зважені оцінки ступенів належності вхідного набору $\left(\mathbf{X}_{*}\right)$ до відповідних терм-множин змінної РЕЗУЛЬТАТИ, максимальна 3 яких визначає підсумок діагностування:

$\mathbf{V}^{(\mathrm{rez})}=\max _{k}\left(\mathbf{V}^{(k)}\left(\mathbf{X}_{*}\right)\right)$

Модель (6)-(7) являє собою певну форму методу Такагі-Сугено [17], де показники активності окремих правил (6) являють собою результати застосування правил логічного виведення, замість найбільш часто використовуваної лінійної функції змінних $\left(\mathbf{X}_{*}\right)$, а (7) подає спосіб узагальнення результатів окремих правил (6). На основі значень (6), (7) можуть бути сформовані різноманітні показники, які визначають відносні порівняльні оцінки результатів (6), наприклад, нормований відсоток тощо. При порівнянні нормованих оцінок показників (6) з установленими рівнями або між собою можливо діагностувати декілька станів (Y) системи. Зазначимо, що засобами моделі нечіткого діагностування (3)-(7) також вирішуються завдання із визначення очікуваних термінів виникнення певних недетермінованих подій, наприклад, щодо параметрів процесів експлуатації ЕД. У цьому разі як множина (Y) використовуються терми лінгвістичної змінної ПЕРІОД («До 3-х місяців», «До 6-х місяців» тощо), а також відповідні набори контрольованих вихідних змінних $(\mathbf{X})$. Результати розрахунків за (6)-(7) дають змогу отримати найбільш достовірні оцінки періодів до очікуваних подій. Сервісне забезпечення зазначених кроків, залежно від конкретного застосування, визначає специфічну складову процедур АнС-Д.

Покажемо застосування (3)-(7) до завдання діагностування об'єктів парку ТС. У роботі [12] було вирішене завдання 3 оптимального управління процесами експлуатації парків стрілочних електричних двигунів. При цьому були враховані умови невизначеності, які можливо подати у формі нечітких величин $[17,18]$. Завдання автоматизації процесів експлуатації вирішене на основі створення інтелектуальної технології контролю парку за поточним станом ЕД. Тут засоби діагностування основані на аналізі даних моніторингу параметрів частотного спектра робочого струму двигуна, а отримання спектральних характеристик струму ЕД реалізовано за допомогою швидкого перетворення Фур'є [12, 23]. Для кожного електродвигуна формується індивідуальна модель (IM), у якій накопичуються і зберігаються поточні характеристики справного стану двигуна. При їх зіставленні та діагностуванні отримують оцінки достовірності виявлених несправностей ЕД. Ці оцінки далі зберігаються в IM ЕД. Для процедур діагностування була застосована нечітка експертна система типу 
Мамдані-Заде [17, 18], розроблена у [12]. Процедура діагностування [12] може бути реалізована на основі АнС-Д таким чином. Як контрольовані параметри $(\mathbf{X})$ обираються величини інтенсивності частот у системі заданих діапазонів, а як терм-множини (Y) змінної РЕЗУЛЬТАТИ - можливі види відмов («обрив секцій якоря», «круговий вогонь» тощо), які обумовлені розподілом інтенсивності спектра за діапазонами. Функції належності (3) обираються у найпростішому, наприклад трикутному вигляді [18], що визначають можливі величини інтенсивності в окремих діапазонах частот. Вагові коефіцієнти (4) дорівнюють 1 для потрібних і 0 - для непотрібних змінних $\mathrm{y}_{k} \in(\mathbf{Y})$ діапазонів частот. При цьому процедури (5)-(7) дають змогу вирішити завдання із діагностування поточних станів ЕД - встановити тип очікуваної відмови.

\section{Висновки \\ Створення засад інтелектуальних систем управління, формування різноманітних засобів телематичного управління $є$ одним із пріоритетних завдань, спрямованих на підвищення ефективності залізничних перевезень в Україні. У статті були досліджені сучасні напрямки розроблення уніфікованих засобів інтелектуальної підтримки АСУ У3, а саме: досліджені питання щодо можливостей формування спеціалізованих інтелектуальних АСУ на основі платформи аналітичних серверів та онтологічних систем. При цьому визначені певні базові функції аналітичних серверів АСУ УЗ, а також методики їх створення 3 огляду на існуючий рівень розвитку інформатизації залізничного транспорту. Уперше у статті подано наукові завдання із формування засад онтологічного забезпечення процесів моделювання у середовищі АСУ УЗ. Для їх реалізації використовуються структури та процедури спеціалізованої прикладної онтологічної системи підтримки конструктивно-продукційного моделювання. Також відзначаються засоби КПМ, які підтримують онтології систем АСУ, що постійно розвиваються, еволюціонують. \\ У статті запропонована узагальнена процедура діагностування характеристик виробничих процесів 3 нечіткими параметрами, яка показує приклад формалізації та реалізації типових завдань процесів автоматизованого управління на основі платформи аналітичних серверів.}

\section{Список використаних джерел}

1. Скалозуб, В. В. Интеллектуальные информационные технологии и системы железнодорожного транспорта [Текст]: монография / В. В. Скалозуб, С. Ю. Цейтлин, М. С. Чередниченко // «Системные технологии моделирования сложных процессов». - Днепр : НМетАУ - ИВК «Системные технологии», 2016. C. 560-589.

2 Жуковицкий, И. В. Создание интеллектуальных систем поддержки принятия решений в единой автоматизированной системе управления грузовыми железнодорожными перевозками Украины [Текст] / И. В. Жуковицкий, В. В. Скалозуб, И. В. Клименко // Системные технологии: Региональный межвуз. сб. науч. работ. - 2018. - Вып. 3 (116). - С. 153-162.

3 Skalozub, V. Development of ontological support of constructive-synthesizing modeling of information systems [Text] / V. Skalozub, V. Illman, V. Shynkarenko // Eastern-European Journal of Enterprise Technologies. - 2017. - Vol. 6/4 (90). P. 58-69. doi: 10.15587/1729-4061.2017.119497

4 Skalozub, V. Ontological support formation for constructive-synthesizing modeling of information systems development processes. [Text] / V. Skalozub, V. Illman, V. Shynkarenko // Eastern-European Journal of Enterprise Technologies. - 2018. - Vol. 5/4 (95). - Р. 55-63.

5 Моделі онтологічної підтримки автоматизованих систем керування залізничними вантажними перевезеннями в Україні [Текст] / В. В. Скалозуб, В. І. Шинкаренко,

С. Ю. Цейтлін, М. С. Чередниченко // Системные технологии: Региональный межвуз. сб. науч. работ. - 2017. Вып. 5 (112). - С. 158-165.

6 Жуковицкий, И. В. Проблемы унификации аналитических процедур в единой автоматизированной системе управления грузовыми железнодорожными перевозками Украины [Текст] / И. В. Жуковицкий, В. В. Скалозуб // Інформаційно-керуючі системи на залізничному транспорті. - 2011. - № 4 C. 86-90.

7 Палагин, А. В. К вопросу построения онтологических систем разного назначения [Текст] / А. В. Палагин, Н. Г. Петренко, А. Е. Митрофанова // Комп'ютерні засоби, мережі та системи. - 2016. - № 15. - С. 5-9.

8 Guarino, N. Understanding, building and using ontologies [Text] / N. Guarino // International Journal of Human-Computer Studies. - 1997. - Vol. 46, N. 2-3. - P. 293-310.

9 Grabusts, P. Ontology-Based Classification System Development Methodology [Text] / P. Grabusts, A. Borisov, L. Aleksejeva // Information Technology and Management Science. - 2015. - Vol. 18, Issue 1. - P. 129-134. doi: 10.1515/itms-2015-0020

10 Beydoun, G. Identification of ontologies to support information systems development [Text] / G. Beydoun //Information Systems. - 2014. - Vol. 46. - P. 45-60. 
11 Kazi1, Z. Ontology-Based System for Conceptual Data Model Evaluation [Text] / Z. Kazi1, L. Kazi1, B. Radulovic1, M. Bhatt // International Arab Journal of Information Technology. - 2016. - Vol. 13, N. 5. P. 542-551.

12 Скалозуб, В. В. Методы интеллектуальных транспортных систем в задачах управления парками объектов железнодорожного транспорта по текущему состоянию [Текст] / В. В. Скалозуб, О. М. Швец, В. Н. Осовик // Питання прикладної математики і математичного моделювання: $3 б$. наук. праць ДНУ ім. О. Гончара. Дніпропетровськ : Ліра, 2014. - С. 229-242.

13 Тарасов, С. В. СУБД для программиста. Базы данных изнутри [Текст] / С. В. Тарасов. - М.: СОЛОН-Пресс, 2015. - 320 с.

14 Паклин, Н. Б. Бизнес-аналитика: от данных к знаниям [Текст] / Н. Б. Паклин, В. И. Орешков. СПб. : Питер, 2009. - 624 с.

15 Моделі i методи соціально-економічного прогнозування [Текст] / В. М. Геєць, Т. С. Клебанова, О. І. Черняк [та ін.]. - Харків : ВД «ІНЖЕК», 2005. - 396 с.

16 Джарратано, Д. Экспертные системы [Текст] / Д. Джарратано, Г. Райли. - М. : ООО «И.Д. Вильямс», 2007. - 1152 с.

17 Рутковская, Д. Нейронные сети, генетические алгоритмы и нечеткие системы [Текст] / Д. Рутковская, М. Пилиньский, Л. Рутковский ; пер. с польск. И. Д. Рудинского. - М. : Горячая линия - Телеком, 2006. - 452 с.

18 Пегат, А. Нечеткое моделирование и управление [Текст] / А. Пегат ; пер. с англ. - М. : БИНОМ. Лаборатория знаний. 2009. - 798 с.

19 Каткова, Т. I. Моделі і методи оцінки, прогнозування та управління стратегічною діяльністю підприємства в умовах невизначеності [Текст] : автореф. дис... д-ра техн. наук : 05.13.03 / Т. І. Каткова. - Харків : ХПІ, 2018. - 33 с.

20 Жуковицкий, И. В. Метод интерактивной динамической оптимизации распределения локомотивов для работы в поездах на основе оценки рисков [Текст] / И. В. Жуковицкий, А. Б. Устенко, О. Л. Зиненко // Інформаційнокеруючі системи на залізничному транспорті. 2006. - № 4. - С.86-91.

21 Козлов, П. А. Построение автоматизированных аналитических систем на железнодорожном транспорте [Текст] / П. А. Козлов, О.В.Осокин // Управление большими системами: сб. тр. Института проблем управления. - 2006. - Вып. 1213. - C. 78.

22 Саати, Т. Метод анализа иерархий [Текст] / Т. Саати, А. Кернес. - М. : Мир, 1991. - 352 с.

23 Айфичер, Э. С. Цифровая обработка сигналов: практический подход [Текст] / Эммануил
С. Айфичер, Барри У. Джервис. - 2-е изд. - М. : Вильямс, 2008. - 992 с.

Жуковицкий И. В., Скалозуб В. В., Устенко А. Б., Клименко И. В. Формирование интеллектуальных информационных технологий железнодорожного транспорта на основе моделей аналитических серверов и онтологических систем.

Аннотация. Исследованы возможности создания унифицированых интеллектуальных автоматизированных систем железнодорожного транспорта на основе платформы аналитических серверов и онтологических систем, предназначенных для поддержки конструктивно-продукционного моделирования, а также функционирование онтологий АСУ которые расширяются и эволюционируют. Для платформы аналитических серверов разработан пример формализации и реализации унифицированных задач диагностирования характеристик производственных процессов с нечеткими параметрами.

Ключевые слова: интеллектуальные автоматизированные системы, аналитические серверы, онтология, диагностирование, нечеткие величины.

Zhukovyts'kyy I. V., Skalozub V. V., Ustenko A. B., Klymenko I. V. Formation of intelligent information technologies of railway transport based on models of analytical servers and ontological systems.

Abstract. The purpose of this work is the research of opportunities of creation of the specialized unified ACS intellectual systems of railway transport on the basis of the platform of analytical servers and ontological systems. These servers and systems are intended for support of constructive-synthesizing model and also for support of functioning of ACS which evolve. Questions and technologies of opportunities of formation of specialized intellectual systems of railway transport on the basis of creation of the platform of analytical servers and ontological systems are investigated. At the same time the unified models and procedures of functioning of analytical servers which are applied to the solution of several versatile tasks are used. Namely - operating control by processes of rational use of the locomotive park, scheduling and management of processes of operation of parks of electric motors. In work the main structures and procedures of specialized applied ontological system which is realized on the basis of model of design and productional model operation are presented. As an example the problem of diagnosing in the conditions of indeterminacy - one of basic tasks of management of processes of operation of parks of railway technical systems is presented. In work basic functions of the ACS 
analytical servers of railway transport are defined, techniques of their creation are shown. Scientific tasks of formation of the principles of ontological ensuring processes of model operation in the environment of ACS of railway transport are for the first time presented.

Keywords: the intellectual automated systems, analytical servers, ontology, diagnosing, fuzzy values.

Надійшла 16.11.2018 p.

Жуковицький Ігор Володимирович, доктор технічних наук, професор, завідувач кафедри електронних обчислювальних машин. Дніпропетровський начіональний університет залізничного транспорту імені академіка $B$. Лазаряна, Дніпро, Україна. E-mail: ivzhukl@ua.fm, http://orcid.org/0000-0002-3491-5976

Скалозуб Владислав Васильович, доктор технічних наук, професор, декан факультету технічної кібернетики. Дніпропетровський національний університет залізничного транспорту імені академіка В. Лазаряна, Дніпро, Украӥна. E-mail: skalozub.vl.v@gmail.com, http://orcid.org/0000-0002-1941-4751

Устенко Андрій Борисович, кандидат технічних наук, дочент кафедри електронних обчислювальних машин. Дніпропетровський національний університет залізничного транспорту імені академіка В. Лазаряна, Дніпро, Україна. E-mail: an.ustenko@gmail.com, http://orcid.org/0000-0002-8677-4781

Кліменко Іван Вікторович, асистент кафедри комп'ютерних інформачійних технологій. Дніпропетровський національний університет залізничного транспорту імені академіка В. Лазаряна, Дніпро, Украӥна. E-mail:_vanya.klymenko@gmail.com, http://orcid.org/0000-0001-5149-3974

Zhukovyts'kyy Igor, Doctor of engineering, Professor, Head of the Department of Electronic Computers, Dnipropetrovsk National University of Railway Transport named after academician Lazaryn, Dnipro, Ukraine, E-mail: ivzhukl@ua.fm, http://orcid.org/0000-0002-3491-5976

Skalozub Vladislav, Doctor of engineering, Professor, Dean of the Faculty of Technical Cybernetics, Dnipropetrovsk National University of Railway Transport named after academician Lazaryn, Dnipro, Ukraine, E-mail: skalozub.vl.v@gmail.com, http://orcid.org/0000-0002-1941$\underline{4751}$

Ustenco Andriy, PhD, Associate Professor of the Department of Electronic Computers, Dnipropetrovsk National University of Railway Transport named after academician Lazaryn, Dnipro, Ukraine, E-mail: an.ustenko@gmail.com, http://orcid.org/0000-0002-8677-4781

Klymenko Ivan, assistant of the Department of Computer Information Technologies, Dnipropetrovsk National University of Railway Transport named after academician Lazaryn, Dnipro, Ukraine, E-mail: vanya.klymenko@gmail.com, http://orcid.org/ 0000-00015149-3974 